\title{
The Influence of Mothers' Parenting Sensitivity on Aggression of Toddlers: The Moderated Mediation Effect of Inhibitory Control and Negative Emotionality
}

\author{
Seon Kyung $\mathrm{Kim}^{1}$, Sunhee $\mathrm{Kim}^{2}$ \\ M. A., Department of Child Development and Family Studies, Pusan National University, Busan, Korea ${ }^{1}$ \\ Professor, Department of Child Development and Family Studies, Pusan National University, Busan, Korea ${ }^{2}$ \\ 어머니의 양육민감성이 걸음마기 아동의 공격성에 미치는 영향: \\ 억제통제와 부정적 정서성의 조절된 매개효과 \\ 김선경 ${ }^{1}$, 김선희 ${ }^{2}$ \\ 부산대학교 아동가족학과 석사 ${ }^{1}$, 부산대학교 아동가족학과 교수 ${ }^{2}$
}

Objectives: The purpose of this study was to examine the moderated mediating effect of negative emotionality through inhibitory control on the relationship between maternal parenting and aggression.

Methods: Participants were 277 toddlers, who were 24 to 35 months, and their mothers and homeroom teachers. A scale of toddlers aggression: TBC (12 questions), a scale of inhibitory control: BRIEF-P (16 questions), a scale of negative emotionality: ECBQ-short (12 questions) and a scale of mother's parenting sensitivity ( 9 questions) were used. Data were analyzed for the moderated mediating effect between variables using PROCESS macro methods.

Results: The main findings were as follows. First, inhibitory control mediated the relationship between mothers' parenting sensitivity and aggression of toddlers. Second, negative emotionality significantly moderated the relationship between mothers' parenting sensitivity and inhibitory control. Last, the mediating effect of inhibitory control was moderated by negative emotionality in the relation between mothers' parenting sensitivity and aggression of toddlers.

Conclusion: These results support Belsky's differential susceptibility model. When the level of negative emotionality is average or above, the more sensitive and responsive the increase in maternal parenting behavior through inhibition control, which has been confirmed to reduce aggression. Implications of the intervention of early intervention program and parent education are also discussed.

Keywords: aggression of toddler, inhibitory control, negative emotionality, mothers' parenting sensitivity, moderated mediating effect

Corresponding Author: Sunhee Kim, Professor, Department of Child Development and Family Studies, Pusan National University, 2, Busandaehak-ro 63beon-gil, Geumjeong-gu, Busan, Korea

E-mail: kremedy@pusan.ac.kr (c) The Korean Association of Child Studies

This is an Open Access article distributed under the terms of the Creative Commons Attribution Non-Commercial License (http:// creativecommons.org/licenses/by-nc/4.0) which permits unrestricted noncommercial use, distribution, and reproduction in any medium, provided the original work is properly cited. 


\section{Introduction}

걸음마기의 아동들은 이전 시기에 비해 자율성과 능동성이 증 가하며, 세상에 대한 강한 호기심과 충동성을 보인다. 또한, 언 어능력 향상 및 자아의 발달을 통해 자기주장과 함께 독립성 이 강해지기 시작한다(B. Park, Kim, Shin, Yun, \& Noh, 2019; Yoon \& Lee, 1999). 이로 인해 기분의 변화가 심해지며, 의도 한 바를 성취하지 못하였을 때 부정적인 정서(negativity)를 강하게 표현하는 등의 공격성을 표출한다(Brownell \& Kopp, 2007; Y. E. Kim, 2014). 이러한 발달적 특성으로 인해 부모들 은 걸음마기의 자녀를 양육하면서 이전과는 다른 어려움에 직 면하게 된다.

공격 행동의 발달적 변화에는 개인차가 존재하지만, 대부 분은 생후 6 개월경부터 분노표출과 신체적 힘의 사용이 관찰 되며, 일부 영아들은 이미 6개월 이전에 높은 수준의 공격성 을 보인다(Hay et al., 2010, 2014). 물론 걸음마기 아동들이 보 이는 공격성은 대부분 정상적인 발달과정을 반영하는 경우가 다수이지만 높은 수준의 공격성이 장기간 지속될 경우 또래갈 등, 사회적 기술 저하, 학업 실패 및 문제행동을 야기할 수 있 다(Campbell, Spieker, Burchinal, Poe, \& The NICHD Early Child Care Research Network, 2006). 따라서 걸음마기 아동이 보이는 공격성을 발달 과정상에 일시적으로 나타나는 현상으로 간주 하기보다 공격성에 관여하는 요인들을 확인하고 이들 요인 간 의 관계를 살펴보는 연구가 필요하다.

아동의 공격성과 관련된 변인으로 크게 환경적 요인과 개 인적 요인으로 나누어 볼 수 있다. 지금까지 환경적 요인으 로 부모의 양육행동과 관련된 연구(Y. E. Kim, 2014; B.-K. Park, 2013; van Aken et al., 2007)가 주로 이루어져 왔으며, 개 인 내적요인으로는 아동의 기질(Lahey et al., 2008; Rothbart \& Bates, 2006)과 자신의 행동 및 정서를 조절하는 자기조절 능 력(Denissen, Thomaes, \& Bushman, 2017), 실행기능(Kong \& $\mathrm{Lim}, 2012)$ 의 관련성이 밝혀지고 있다. 아동의 공격성은 이 러한 환경적 요인들과 아동 내적인 유전적, 심리적 요인들이 서로 상호작용한 결과임이 밝혀지고 있으나(J. Chung, 2017; Verhoeven, Junger, van Aken, Deković, \& van Aken, 2010) 주로 학령 전의 유아를 대상으로 한 연구가 다수를 이룬다. 앞서 언 급한 것처럼 걸음마기 아동은 자기주장이 강해지고 부정성이 증가하여 자신의 정서를 강하게 표현하는 등 부모와의 갈등이 높아지는 시기로 이에 대한 발달적 특성을 고려하여 아동이 보이는 공격성에 대해 어머니의 양육 변인과 아동 내적 요인 들이 서로 어떠한 조건과정에서 어떻게 영향을 미치는지 심층
적으로 살펴보고자 한다.

걸음마기 아동은 가정에서 어머니와 보내는 시간이 상대 적으로 많고 이 시기에 제공되는 양육환경은 아동의 발달에 지대한 영향을 미친다. 특히, 자녀의 욕구에 대해 민감하게 느 끼고 온정적으로 반응하는 것은 매우 중요하므로 어머니의 양육민감성(parenting sensitivity)을 고려할 수 있다(Ainsworth, Blehar, Waters, \& Wall 1978; N. Hong \& Bang, 2018; Lee, 2005; Shim \& Woo, 2019). 어머니의 양육민감성은 자녀가 요구하 는 신호에 대해 민감하게 인지하고 일관되게 반응하는 부모의 양육 능력을 말하며(Ainsworth, Bell, \& Stayton, 1971), 따뜻함 과 정서적 지원과 같은 양육 행동을 포함한다(Stams, Juffer, \& Van IJzendoorn, 2002). 양육민감성이 높은 어머니의 경우 자 녀와의 관계에서 안정적인 애착을 형성하고(Bowlby, 2005; N. Hong \& Bang, 2018), 자녀의 정서적 신호에 수용적이고 민감 하게 반응하여 아동의 사회.정서적 기능에 밀접한 영향을 미 친다(Belsky, 1984; J. Kim, 2016). 따라서 걸음마기 아동의 발달 에 있어 긍정적인 영향을 미치는 어머니의 양육민감성이 아동 의 개인내적 요인들과 서로 어떠한 관련성이 있는지 살펴본다 면 걸음마기 아동의 공격성 발달에 대한 구체적인 정보를 제 공할 수 있을 것이다.

아동의 공격성은 2-3세 동안 최고조에 달한 다음 5세부터 감소하는 경향을 보인다(Hay et al., 2014; NICHD Early Child Care Research Network \& Arsenio, 2000). 특히, 걸음마기 아동 이 보이는 신체적 공격은 의도적이기보다는 다소 격렬한 좌절 이나 분노, 두려움에 의해 촉발된 충동적인 행동 억제의 실패 로 볼 수 있다(Tremblay, 2000). 아동은 점차적 성장하면서 자 기조절의 발달과 더불어 유연한 대응 방식으로 대처할 수 있 는 능력이 향상됨에 따라 충동적이고 공격적인 행동이 감소 한다(Tremblay, 2010). 이처럼 아동들은 성장해 가면서 공격 행 동 표출 등의 부적절하거나 충동적인 행동을 억제하거나 조 절하는 방법을 배워나가기 시작하는데 이러한 자기조절 능 력은 실행기능과 밀접한 관련성을 보인다(Bernier, Carlson, \& Whipple, 2010; Blair \& Ursache, 2011). 실행기능을 발달시키 는데 있어 부모의 초기 양육행동은 주요한 역할로 작용한다 (Valcan, Davis, \& Pino-Pasternak, 2018). 부모는 생애 초기부터 자녀의 행동에 대한 외부조절자 역할을 하며, 점진적으로 내 부 조절능력을 발전시키기 위해 자녀의 자기조절 능력을 돕는 역할을 한다(Grossmann \& Grossmann, 1991; Spangler, Schieche, Ilg, Maier, \& Ackermann, 1994). 실제로 어머니의 양육태도와 문제행동의 관계에서 아동의 실행기능에 대해 살펴본 국내외 선행연구들에 의하면 어머니의 양육행동과 공격성간의 관계 
에서 실행기능이 매개적 역할을 하는 것으로 밝혀지고 있다 (Kong \& Lim, 2012; B. Park \& Noh, 2020; Sulik et al., 2015; van Dijk et al., 2017).

실행기능은 작업 기억(working memory), 억제통제(inhibitory control), 전환 능력(shifting)을 포함한다(Diamond, 2013). 이 중 억제통제는 사회적 능력을 예측하고 공격적 충동을 억제 하는 능력에 있어 중요한 요인으로 주목된다. 억제통제는 목 표 달성을 위해 부적절하거나 간섭을 일으키는 자극을 억제 하거나 통제하는 능력을 말한다(Best, Miller, \& Jones, 2009). 즉, 일상생활에서 아동이 흥분하였을 때 고함치는 것 같은 지 배적 반응을 억제하고 상황에 적절한 행동을 할 수 있도록 돕 는 인지적 조절능력을 말한다(Garon, Bryson, \& Smith, 2008). Gandolfi, Viterbori, Traverso와 Usai (2014)는 걸음마시기에 억 제통제가 충동적 또는 지배적 반응을 억제하는 능력인 반응 억제와 간섭정보를 억제하는 능력인 간섭억제로 구분될 수 있음을 제시하였다. 또한, 갈등적 상황에서 자신의 행동을 외 부의 요구에 따라 지연하거나 순응하는 것과 같은 행동으로 조절할 수 있도록 돕는 억제통제는 생후 초기부터 점진적으 로 발달하기 시작하다 만 2세부터 빠르게 성장하기 시작하 므로 보다 더 주의 깊게 살펴봐야 할 것이다(Diamond, 2016; Maccoby, 2007; Morasch \& Bell, 2011; Roskam, 2018).

한편, 아동의 공격성은 타고난 기질적 성향과도 밀접한 관 련성이 있다(Lahey et al., 2008; B.-K. Park, 2013; Rothbart \& Bates, 2006). 특히, 부정적 정서성과의 관련된 연구가 가장 일 관되게 보고된다(Pluess \& Belsky, 2010; van Zeijl et al., 2007). 부정적 정서성(negative emotionality)은 생애 초기부터 관찰되 는 특성으로 스트레스에 대해 쉽게 반응하여 울음과 짜증, 흥 분 등의 부정적 정서를 강하게 표현하는 정도를 의미한다. 생 애 초기에 나타나는 부정적인 감정은 이후의 자기조절 미숙 을 포함하여 문제행동에 대한 위험성을 증가시키는 취약성으 로 고려되어져 왔다(Bates, Pettit, Dodge, \& Ridge, 1998; Lahey et al., 2008). 하지만 부정적 정서성 수준이 높은 영유아가 합 리적인 훈육을 경험한 경우 쉬운 기질의 영유아보다 행동문 제를 더 적게 보였으며(van Zeijl et al., 2007), 같은 맥락으로 높 은 부정적 정서성을 보이는 유아에게 온정적이고 민감한 양 육 경험을 제공하였을 때 양육의 유익성이 가장 높았다(Pluess \& Belsky, 2010). 따라서 부정적 정서성을 걸음마기 아동이 보 이는 충동적인 행동 조절의 어려움으로 인한 공격 행동 표출 을 취약성으로 간주하기보다는 환경적 특성에 따라 부정적 정 서성의 영향이 달라질 수 있으므로 환경에 대한 민감성이라는 측면에서 살펴볼 필요가 있다.
Cipriano-Essel, Skowron, Stifter와 Teti (2013)는 부정적 정서 성 수준이 높은 유아에게서만 어머니의 온정적이고 지지적인 양육행동이 억제통제를 예측하였으며, 이러한 민감성은 순한 기질을 가진 아동들에게는 유익한 효과가 없는 것으로 보고되 었다. 이처럼 부모의 온정적이고 지지적인 양육 행동은 아동 의 실행기능의 발달을 촉진하는 요인으로써 아동의 조절 능력 을 지원하여 발달에 긍정적인 영향을 미친다(Blair et al., 2014; Roskam, 2018; Stams et al., 2002). 이때 부정적 정서성의 수준 에 따라 양육의 유익한 효과가 다르게 나타남으로써 자신의 행동을 조절하는 능력인 억제통제에 차이를 가져올 수 있다.

Belsky (1997)의 차별적 민감성 가설(differential susceptibility model)에 따르면 부정적 정서성 수준이 높은 아동들은 긍정적 인 환경에 대한 민감성이 높아서 부정적 정서성 수준이 낮은 아동들보다 더 높은 적응 수준을 보인다. 이 가설은 생애 초기 부정적 정서와 열악하고 부정적인 부모-자녀 관계를 취약성 으로만 고려하는 것은 아동의 개성과 환경 사이의 또 다른 중 요한 상호작용 형태를 제한하고 있음을 지적하고, 아동의 기 질을 취약성이 아닌 민감성의 측면에서 다루어야 함을 제안한 다. 부정적 정서성이 높은 아동들은 기질적 특성으로 인해 사 회정서행동에 어려움을 경험하며 발달적 과업의 성취와 자신 의 행동을 조절하는 억제통제의 발달에 어려움을 직면하게 된 다. 하지만 초기에 형성된 긍정적인 관계 및 어머니의 지지적 이고 온정적인 양육 행동에 따라 부정적 정서성이 높은 아동 들에게 미치는 위험을 완화할 수 있으며, 이러한 관계가 아동 들에게 보다 긍정적인 발달 결과를 가져올 수 있다(Belsky \& Pluess, 2009; Kochanska, Kim, Barry, \& Philibert, 2011).

지금까지 살펴본 어머니의 양육민감성, 걸음마기 아동의 공격성, 억제통제 및 부정적 정서성의 관계를 고찰해보면, 부 정적 정서성이 높은 아동의 경우 어머니가 제시하는 온정적 인 환경과 지지적이고 반응적인 양육의 유익성이 아동의 억제 통제를 증진할 것이며 결과적으로 아동의 공격성 수준을 낮출 수 있다. 즉, 어머니의 양육민감성과 걸음마기 아동의 공격성 간의 관계에서 억제통제의 매개효과가 부정적 정서성 수준에 의해 조절되는 효과가 있음을 유추해볼 수 있다.

따라서 본 연구는 기존의 연구들에서보다 확장하여 양육민 감성이 억제통제를 매개로 걸음마기 공격성에 미치는 관계에 서 부정적 정서성의 역할을 동시에 검증하기 위해 조절된 매 개(moderated mediation) 모형을 적용하였다. 조절된 매개 모형 은 조건부과정모형으로서, 조절효과와 매개효과를 단순히 확 인하는 관점에서 나아가 조절변인과 매개변인을 단일모형에 결합하여 전체적인 변인들간의 복합해진 관계를 깊이 있게 검 
증할 수 있는 방법이다(H.-K. Lee, 2016). 즉, 예측변인이 매개 변인을 통해 결과변인에 영향을 미치는 간접효과가 조절변인 에 따라 달라지는지 확인할 수 있다.

본 연구의 목적은 어머니의 양육민감성이 걸음마기 아동의 공격성에 영향을 미치는 관계에서 억제통제의 매개 역할을 확 인하고, 부정적 정서성의 조절효과가 어떻게, 언제 발생하는 지를 검증하는 것이다. 걸음마기 아동의 공격성에 미칠 수 있 는 변인들을 통합적으로 살펴봄으로써 부정적 정서성의 기질 적 특성과 관련하여 어머니의 양육행동뿐만 아니라 억제통제 의 역할에 대해 기초자료를 제공할 것이다. 또한, 예방적 차원 을 넘어 높은 공격성을 보이는 아동들에게 실천 가능한 조기 중재 방안을 제공하고자 한다.

\section{연구문제 1}

걸음마기 아동의 억제통제는 어머니의 양육민감성과 걸음마 기 아동의 공격성에 미치는 영향을 매개하는가?

\section{연구문제 2}

걸음마기 아동의 부정적 정서성은 어머니의 양육민감성이 걸 음마기 아동의 억제통제 사이에 미치는 영향을 조절하는가?

\section{연구문제 3}

어머니의 양육민감성, 걸음마기 아동의 억제통제, 공격성의 관계에서 부정적 정서성의 조절된 매개효과가 나타나는가?

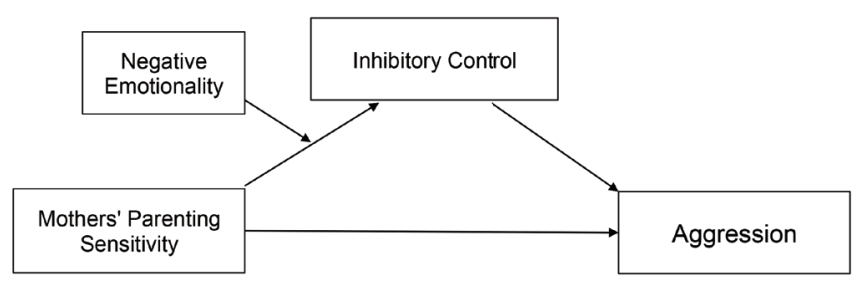

Figure 1. Study model.

\section{Methods}

\section{연구대상}

본 연구의 대상은 $\mathrm{B}$ 시와 $\mathrm{G}$ 에 소재한 34곳의 어린이집에 재원 하고 있는 24-36개월 걸음마기 아동 277명과 그들의 어머니이 다. 걸음마기 아동의 공격성에 대해 객관적이고 타당한 정보를 얻기 위해 담당 보육교사가 보고하였다. 277 명 아동의 평균 연
령은 30.42 개월 $(S D=3.97)$ 이었으며, 남아 137 명 $(49.5 \%)$ 과 여 아 140 명(50.5\%)으로 구성되었다. 어머니의 연령은 35-40세가 116 명(41.9\%)으로 가장 많았고, 31-35세가 112명(40.4\%), 40-45 세 32명(11.6\%), 30세 이하 17명(6.1\%) 순이었다. 교육수준은 대 학교 졸업이 159명(57.4\%)으로 가장 많았고, 전문대 졸업이 79 명 $(28.5 \%)$, 대학원 이상이 23명(8.3\%), 고등학교 졸업이 16명 (5.8\%) 순이었다. 월 가구소득은 301-400만원 미만이 93가구 (33.6\%)로 가장 많았고, 501만원 이상 81가구(29.2\%), 401-500 미만 63가구(23.1\%), 201-300만원 미만 32가구(11.6\%), 200만원 미만 7가구(2.5\%) 순이었다. 89명의 담당 교사의 경력은 5년 이 상 7년 미만이 22명(24.7\%)으로 가장 많았으며, 7년 이상 10년 미만이 20명(22.5\%), 3년 이상 5년 미만이 17명(19.1\%), 1년 이상 3 년 미만이 14 명(15.7\%), 10년 이상이 10명(11.2\%), 1년 미만이 6 명(6.7\%) 순이었다. 교육 수준은 전문대 졸업이 42명(47.2\%)로 가장 많았으며, 대학교 졸업이 30 명(33.7\%), 보육교사 교육원 졸업이 15 명(16.8\%), 대학원 이상이 2명(2.2\%) 순이었다.

\section{연구도구}

\section{어머니의 양육민감성}

어머니의 양육민감성을 측정하기 위해 The Parental Style Questionnaire (PSQ; Bornstein et al., 1996)를 H. M. Lee (2006)가 번 안한 척도를 Shim과 Woo (2019)가 적용한 것을 토대로 사용하 였다. 사회적 상호작용 유형은 어머니가 자녀와 맺는 관계적 상황에서 양육행동을 의미하며, 어머니의 온정성 및 반응성 을 포괄하는 개념이다(Shim \& Woo, 2019). PSQ는 어머니가 측정하는 질문지로 하위영역은 사회적 상호작용 유형, 한계설 정 유형, 가르치는 유형으로 구성되어 있으나 본 연구에서는 사회적 상호작용 유형의 9문항을 사용하였으며, 문항에는 "나 는 내 아이가 힘들어하거나 불편해하면 즉시 적절하게 반응한 다.", "나는 내 아이에게 긍정적이고 애정적이며 따뜻한 관심 을 보인다."의 내용이 포함되었다. 각 문항은 거의 그렇지 않 다(1점), 아주 가끔 그렇다(2점), 때때로 그렇다(3점), 자주 그 렇다(4점), 항상 그렇다(5점)의 5점 척도로 측정되고, 점수가 높을수록 양육민감성이 높은 것을 의미한다. 본 연구에서 사 용된 척도의 신뢰도 계수(Cronbach's $\alpha$ )는 .81로 나타났다.

\section{걸음마기 아동의 억제통제}

걸음마기 아동의 억제통제를 측정하기 위해 2 세 0 개월에서 5 
세 11개월 유아를 대상으로 Isquith, Gioia와 Espy (2004)의 실 행기능 평정척도-유아용(BRIEF-P)을 Seo와 Park (2011)이 번 안한 척도를 사용하였다. BRIEF-P는 어머니가 측정하는 질문 지로 다양한 상황에서 유아의 일상적인 실행기능을 평가하는 5 가지 하위항목(억제, 전환, 작업기억, 정서조절, 계획·조직 화)으로 구성된다. 본 연구에서는 걸음마기 아동의 충동 조절 능력 또는 동작, 반응 및 동작을 중지/변환하는 능력을 측정하 기 위해 억제 16 문항을 사용하였다. 각 문항은 전혀 그렇지 않 다(1점), 때때로 그렇다(2점), 자주 그렇다(3점)의 3점 척도로 측정되고, 점수가 높을수록 억제통제가 낮은 것을 의미하므로 본 연구에서는 점수를 역코딩하여 변환하였다. 본 연구에서 사용된 척도의 신뢰도 계수(Cronbach's $\alpha$ )는 .91로 나타났다.

\section{걸음마기 아동의 부정적 정서성}

걸음마기 아동의 부정적 정서성을 측정하기 위해 18 개월에 서 36개월 영아용 기질 측정도구인 한국판 Rothbart 걸음마 기 기질 척도(Early Childhood Behavior Questionnaire [ECBQ]) 축약형을 사용하였다(K. B. Yun, 2012). ECBQ의 축약형은 어 머니가 측정하는 질문지로 하위영역은 부정적 정서성, 외향 성, 의도적 통제로 구성된다. 본 연구에서는 부정적 정서에 해당하는 12 문항을 사용하였다. 각 문항은 7점 척도(언제나 그렇지 않다, 대개 그렇지 않다, 그렇지 않는 편이다, 반반이 다, 그런 편이다, 대개는 그렇다, 언제나 그렇다)로 평정하였 으며, 점수가 높을수록 부정적 정서성이 높은 것을 의미한다. 본 연구에서 사용된 척도의 신뢰도 계수(Cronbach's $\alpha$ )는 .82 로 나타났다.

\section{걸음마기 아동의 공격성}

걸음마기 아동의 공격성을 측정하기 위하여 Larzelere, Amberson과 Martin (1989)에 의해 개발된 Toddler Behavior Checklist (TBC)를 B. Y. Kim (2005)이 수정·보완한 것을 사 용하였다. $\mathrm{TBC}$ 는 담당 보육교사가 측정하는 질문지로 공격 적 행동, 반항적 행동, 정서불안 행동, 미성숙 행동, 위축 행 동으로 구성된다. 본 연구에서는 공격적 행동 12 문항을 사 용하였다. 각 문항은 전혀없다(1점), 가끔 발생한다(2점), 자 주 발생한다(3점), 아주 많이 발생한다(4점)의 4점 척도로 평 정하였으며, 점수가 높을수록 공격성이 높음을 의미한다. 본 연구에서 사용된 척도의 신뢰도 계수(Cronbach's $\alpha$ )는 .85로 나타났다.

\section{연구절차}

걸음마기 아동의 공격성, 억제통제, 부정적 정서성과 어머니 의 양육민감성 및 조사대상자의 일반적 특성에 관한 내용으 로 설문지를 구성하여 2020년 8월 10일부터 2020년 10월 5일 까지 설문조사를 통해 자료를 수집하였다. 각 시설의 보육교 사에게 어머니용과 교사용의 설문지에 대한 질문내용을 설 명한 뒤 가정통신문을 통해 협조를 구하여 아동을 통해 설문 지를 가정에 배포하였으며, 보육교사가 아동의 공격성에 대 해 평정한 설문지와 어머니용 설문지를 함께 회수하였다. 총 310 부가 회수되었으며, 이 중 연령이 맞지 않거나 불성실한 응답 자료 33 부를 제외한 277 부가 최종 분석 자료로 사용되 었다.

\section{자료분석}

자료분석은 SPSS 20.0 (IBM Co., Armonk, NY)과 Process macro version 3.5 (Hayes, 2018)를 사용하였다. SPSS 20.0을 통해 기 술통계와 상관관계 분석을 실시하고, 어머니의 양육민감성 과 걸음마기 아동의 공격성의 간의 관계에서 억제통제와 부 정적 정서성의 매개효과, 조절효과 및 조절된 매개효과를 살 펴보기 위해 Process macro의 Model 4, Model 1, Model 8을 사 용하여 검증하였으며, 유의성을 검증하기 위해 부트스트래핑 (bootstrapping)을 실시하였다.

\section{Results}

\section{주요 변인들 간의 관계}

걸음마기 아동의 공격성, 억제통제, 부정적 정서성과 어머니 의 양육민감성의 상관관계를 살펴보기 위해 각 변인들의 기 술통계치와 Pearson 적률상관계수를 산출한 결과는 Table 1과 같다.

Table 1 에 의하면, 각 변인 평균의 경우 어머니의 양육민감 성은 $3.94(S D=.51)$, 걸음마기 아동의 억제통제는 $2.52(S D=$ $.41)$, 걸음마기 아동의 부정적 정서성은 $3.67(S D=.99)$, 걸음 마기 아동의 공격성은 $1.71(S D=.59)$ 로 나타났다. 각 변인의 왜도의 절대값 2.0 이내, 첨도의 절대값이 4.0 이내로 이를 포 함하므로 본 자료는 정규성 가정을 충족하여(S. Hong, Malik, $\&$ Lee, 2003) 자료 분석에 적합한 것으로 확인하였다. 
Table 1

Means, Standard Deviations, and Correlations Among Variables

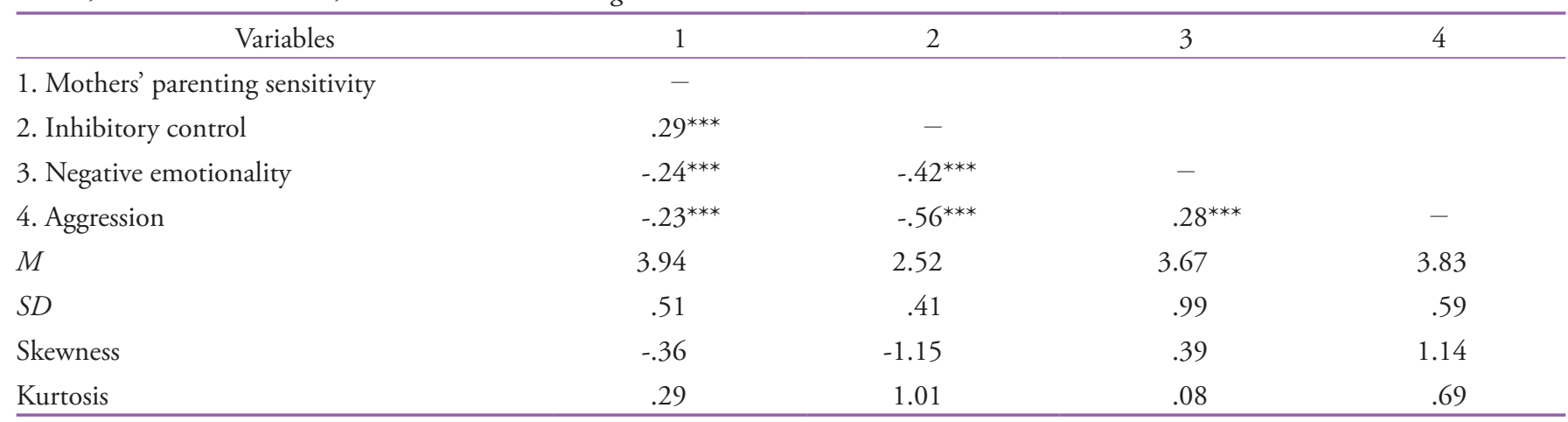

Note. $N=277$.

*** $p<.001$.

다음으로 걸음마기 아동의 공격성은 어머니의 양육민감성, 걸음마기 아동의 억제통제와 부정적 정서성 모두와 유의한 상 관이 있었다. Table 1 에 의하면 어머니의 양육민감성과의 상관 관계를 살펴본 결과, 어머니의 양육민감성과 걸음마기 아동의 억제통제 $(r=.29, p<.001)$ 는 정적 상관으로 유의미하게 나타 났다. 반면, 어머니의 양육 민감성과 걸음마기 아동의 부정적 정서성 $(r=-.24, p<.001)$, 공격성 $(r=-.23, p<.001)$ 은 부적 상 관으로 유의미하게 나타났다. 즉, 어머니의 양육민감성이 높 을수록, 걸음마기 아동의 억제통제 수준이 높았지만, 부정적 정서성과 공격성의 수준이 낮았다. 그리고 걸음마기 아동의 억제통제와의 상관관계를 살펴본 결과, 걸음마기 아동의 억제 통제와 부정적 정서성 $(r=-.24, p<.001)$ 과 공격성 $(r=-.42, p<$ .001)은 부적 상관으로 유의미하게 나타났다. 즉, 걸음마기 아 동의 억제통제 능력이 높을수록 부정적 정서성과 공격성의 수 준이 낮았다. 마지막으로 걸음마기 아동의 부정적 정서성과 공격성 간의 상관관계를 살펴본 결과, 걸음마기 아동의 부정 적 정서성은 공격성 $(r=.28, p<.001)$ 과 정적 상관으로 유의미 하게 나타났다. 즉, 걸음마기 아동의 부정적 정서성이 높을수 록 공격성 수준이 높았다.

\section{어머니의 양육민감성과 걸음마기 아동의 공격성 간의 영향에서 억제통제의 매개효과}

어머니의 양육민감성과 걸음마기 아동의 공격성 사이에서 걸음마기 아동의 억제통제의 매개효과를 검증하기 위하여 Hayes (2018)의 PROCESS macro Model 4를 적용하였으며, 부 트스트랩 샘플은 5,000개로 지정한 후 신뢰구간은 95\%로 설 정하여 분석을 실시한 결과는 Table 2, Figure 2와 같다.

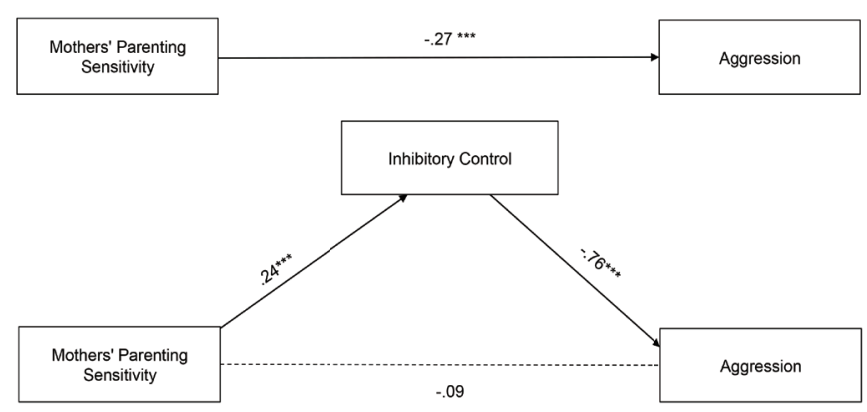

Figure 2. Results of mediating effect of inhibitory control in the relationship between mothers' parenting sensitivity and aggression of toddlers.

${ }^{* * *} p<.001$.

Table 2에 의하면, 어머니의 양육민감성 $(\beta=-.09)$ 은 걸음마 기 공격성에 미치는 영향이 유의하지 않았다. 반면, 억제통제 $(\beta=-.76, p<.001)$ 는 걸음마기의 공격성에 부적인 영향을 미 쳤으며, 어머니의 양육민감성은 억제통제에 정적인 영향을 미 쳤다 $(\beta=.24, p<.001)$. 또한, 어머니의 양육민감성에서 걸음 마기 아동의 공격성 간의 총 효과는 $\beta=-.27(p<.001)$ 이었으 나 매개변수인 억제통제가 투입되면서 어머니의 양육민감성 에서 걸음마기 아동의 공격성 간 경로의 직접효과가 $\beta=-.09$ 로 감소하여 억제통제가 매개하였음을 알 수 있다. 이와 같은 결과를 통해 어머니의 양육민감성이 걸음마기 아동의 공격성 에 미치는 영향에서 억제통제는 완전매개 역할을 하고 있음을 확인하였다.

어머니의 양육민감성과 걸음마기 아동의 공격성의 간접효 과를 부트스트래핑을 활용하여 검증한 결과 Table 3 과 같다.

Table 3에 의하면, 어머니의 양육민감성이 걸음마기 억제통 제의 매개효과로 인해 걸음마기 아동의 공격성에 영향을 미치 
Table 2

Results of Mediating Effect of Inhibitory Control in the Relationship Between Mothers' Parenting Sensitivity and Aggression of Toddlers

\begin{tabular}{lllllllc}
\hline & & & & & & \multicolumn{2}{c}{$95 \%$} \\
\cline { 5 - 8 } & Pathway & & $\beta$ & $S E$ & $t$ & LLCI & ULCI \\
\hline Mothers' parenting sensitivity & $\rightarrow$ & Inhibitory control & .24 & .04 & $5.15^{* * *}$ & .14 & .33 \\
Mothers' parenting sensitivity & $\rightarrow$ & Aggression & -.09 & .05 & -1.48 & -.21 & .03 \\
Inhibitory control & $\rightarrow$ & Aggression & -.76 & .07 & $-10.47^{* * *}$ & -.91 & -.62 \\
\hline
\end{tabular}

Note. $N=277$. LLCI = Lower limit confidence interval; ULCL = Upper licit confidence interval.

${ }^{* * *} p<.001$.

Table 3

Results of Mediating Effect of Inhibitory Control in the Relationship Between Mothers' Parenting Sensitivity and Aggression of Toddlers

\begin{tabular}{lcccc}
\hline & Effect & $S E$ & LLCI & ULCI \\
\hline Total effect & -.27 & .07 & -.40 & -.14 \\
Direct effect & -.09 & .06 & -.21 & .03 \\
Indirect effect & -.18 & .04 & -.27 & -.10 \\
\hline
\end{tabular}

Note. $N=277$. LLCI $=$ Lower limit confidence interval; ULCL $=$ Upper licit confidence interval.

Table 4

Results of Moderating Effect of Negative Emotionalityin the Relationship Between Mothers' Parenting Sensitivity and Inhibitory Control of Toddlers

\begin{tabular}{|c|c|c|c|c|c|}
\hline \multirow[b]{2}{*}{ Variables } & \multirow[b]{2}{*}{$\beta$} & \multirow[b]{2}{*}{$S E$} & \multirow[b]{2}{*}{$t$} & \multicolumn{2}{|c|}{$95 \%$} \\
\hline & & & & LLCI & ULCI \\
\hline Mothers' parenting sensitivity (A) & .13 & .04 & $3.03^{* *}$ & .04 & .22 \\
\hline Negative emotionality (B) & -.16 & .02 & $-7.15^{* * *}$ & -.20 & -.11 \\
\hline \multirow[t]{4}{*}{$\mathrm{A} \times \mathrm{B}$} & .09 & .03 & $2.49^{*}$ & .02 & .17 \\
\hline & \multicolumn{2}{|c|}{$R^{2}$} & $F$ & & $p$ \\
\hline & \multicolumn{2}{|c|}{.01} & & $6.19^{*}$ & .013 \\
\hline & & & & \multicolumn{2}{|c|}{$95 \%$} \\
\hline Conditioning Values & Effect & $S E$ & $t$ & LLCI & ULCI \\
\hline$-1 S D(-.99)$ & .04 & .06 & .62 & -.08 & .17 \\
\hline$M(0)$ & .13 & .04 & 3.01 & .04 & .22 \\
\hline$+1 S D(.99)$ & .23 & .05 & 4.50 & .13 & .33 \\
\hline
\end{tabular}

Note. $N=277$. LLCI $=$ Lower limit confidence interval; ULCL $=$ Upper licit confidence interval.

${ }^{*} p<.05 .{ }^{* *} p<.01 .{ }^{* * *} p<.001$.

는 간접효과 크기는 $\beta=-.18$, 신뢰구간이 $(-.27,-.10)$ 으로 나타 나 상한값과 하한값 사이에 0이 존재하지 않아 간접효과는 유 의한 것으로 밝혀졌다.

\section{어머니의 양육민감성과 걸음마기 아동의 억제 통제에서 부정적 정서성의 조절효과}

어머니의 양육민감성과 걸음마기 아동의 억제통제 사이에서 걸 음마기 아동의 부정적 정서성의 조절효과를 검증하기 위하여 Hayes (2018)의 PROCESS macro Model 1을 적용하였다. 다중공
선성 문제를 최소화하기 위해 독립변인과 조절변인을 평균중 심화 하였으며, 부트스트랩 샘플은 5,000개로 지정한 후 신뢰구 간은 $95 \%$ 로 설정하여 분석을 실시한 결과는 Table 4 와 같다.

Table 4에 의하면, 어머니의 양육민감성은 억제통제에 정적 으로 유의한 영향을 미쳤고 $(\beta=.13, p<.01)$, 걸음마기 아동의 부정적 정서성은 걸음마기 아동의 억제통제에 유의한 부적 영 향을 미쳤다 $(\beta=-.16, p<.001)$. 어머니의 양육민감성과 걸음마 기 아동의 부정적 정서성의 상호작용항은 억제통제에 정적으 로 유의한 영향을 주었고 $(\beta=.09, p<.01)$, 상호작용에 따른 $R^{2}$ 의 증가량도 유의미하여 $\left(\Delta R^{2}=.01, p<.01\right)$ 조절효과가 있었다. 


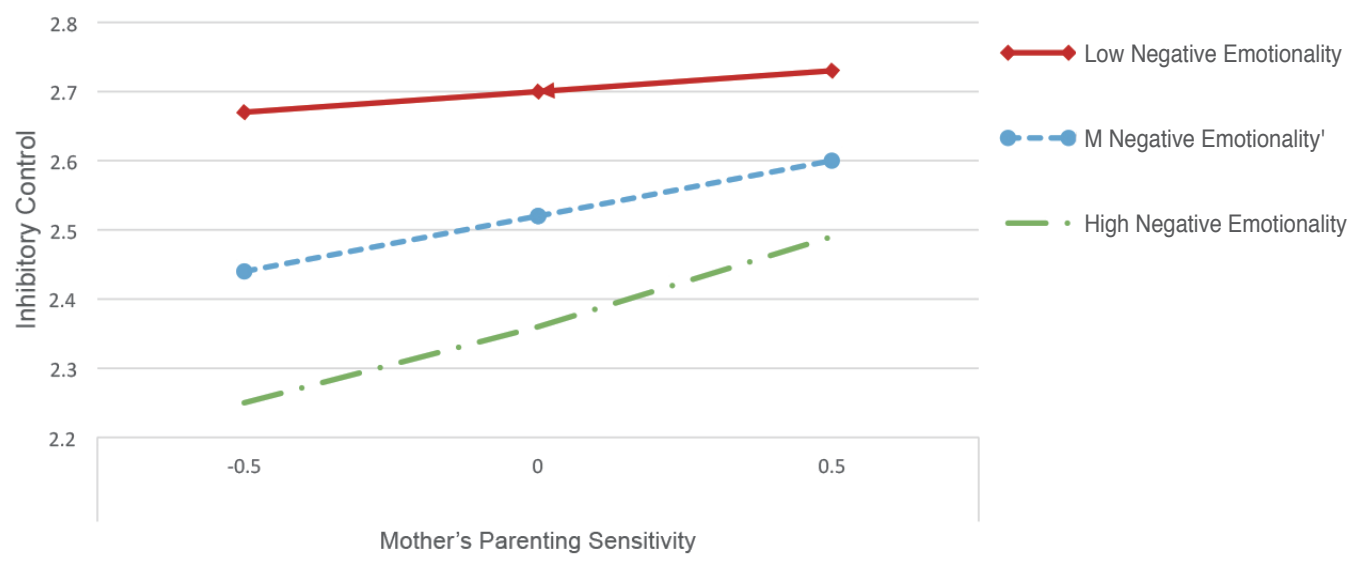

Figure 3. Moderating effects of negative emotionality on the relationship between mother's parenting sensitivity and inhibitory control.

다음으로 조절효과의 구체적인 영향을 확인하기 위해 PROCESS macro를 통한 회귀선의 유의성검증을 실시한 결과 는 Figure 3에 제시된 바와 같다.

Figure 3 에 의하면, 어머니의 양육민감성과 걸음마기 아동 의 억제통제에 대한 조건부효과는 부정적 정서성의 값이 평균 수준 $(M)$ 과 높은 수준 $(+1 S D)$ 에서는 유의하였으나 낮은 수준 $(-1 S D)$ 에서는 조건부가 유의하지 않았다. 따라서 걸음마기 아 동의 부정적 정서성이 낮을 때 어머니의 양육민감성이 걸음마 기 아동의 억제통제에 미치는 영향은 효과가 없었다. 즉, 부정 적 정서성의 수준이 평균이나 그 이상의 경우 어머니의 양육 민감성이 높아질수록 억제통제도 높아진 반면, 부정적 정서성 이 낮은 수준의 경우에는 어머니의 양육민감성이 억제통제를 예측하지 못하는 것으로 나타났다.

\section{어머니의 양육민감성 걸음마기 아동의 억제통제, 공격성의 영향에서 부정적 정서성의 조절된 매개 효과}

앞에서 살펴본 분석 결과를 바탕으로 어머니의 양육민감성이 걸음마기 아동의 억제통제를 매개로 하여 걸음마기 아동의 공 격성에 영향을 미치는 과정에서 걸음마기 아동의 부정적 정서 성의 조절효과가 있는지, 즉 어머니의 양육민감성과 걸음마기 아동의 부정적 정서성간의 상호작용에 의한 걸음마기 아동의 공격성에 이르는 경로(직접효과)와 상호작용항이 걸음마기 아동의 억제통제를 거쳐 걸음마기 아동의 공격성에 이르는 경 로(간접효과)를 통해 조절된 매개효과가 있는지를 검증하기 위하여 Hayes (2018)가 제안한 PROCESS macro의 Model 8을
적용하였다. 다중공선성의 문제를 최소화하기 위하여 독립변 인과 매개변인, 조절변인을 평균중심화하였으며, 부트스트랩 샘플은 5,000개로 지정한 후 신뢰구간은 $95 \%$ 로 설정하여 분 석을 실시한 결과는 Table 5, Figure 4와 같다.

Table 5에 의하면, 어머니의 양육민감성과 걸음마기 아동의 부정적 정서성간의 상호작용에 의한 걸음마기 아동의 공격성 에 이르는 경로(직접효과)를 살펴본 결과, 어머니의 양육민감 성 $(\beta=-.07)$, 걸음마기 아동의 부정적 정서성 $(\beta=.02)$, 양육민 감성과 부정적 정서성의 상호작용항 $(\beta=.04)$ 로 유의하지 않 았으나 걸음마기 아동의 억제통제 $(\beta=-.73, p<.001)$ 는 부적인 영향을 미쳤다.

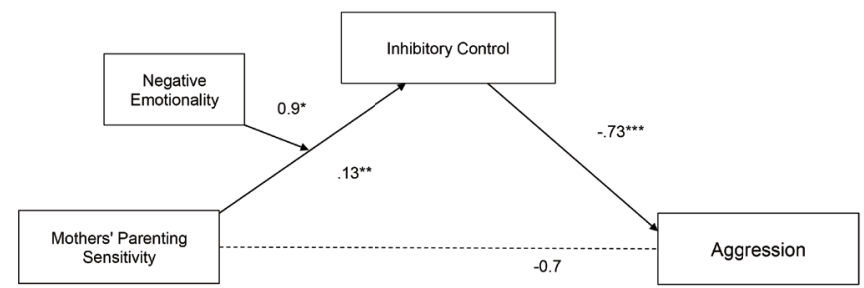

Figure 4. Statistical diagram.

${ }^{*} p<.05 .{ }^{* *} p<.01 .{ }^{* * *} p<.001$.

반면, 상호작용항이 걸음마기 아동의 억제통제를 거쳐 걸 음마기 아동의 공격성에 이르는 경로(간접효과)를 살펴본 결 과, 어머니의 양육민감성과 부정적 정서성의 상호작용항 $(\beta=$ $.09, p<.01)$ 은 정적인 영향을 미쳤다.

아울러 조절된 매개지수는 $\beta=-.07$ 로 나타나 신뢰 구간 $(-.13,-.00)$ 에 0 이 포함되지 않아 걸음마기 아동의 부정적 정서 성의 조절된 매개효과는 유의한 것으로 나타났다. 이와 같은 
Table 5

Results of Moderated Mediation Effectof Negative Emotionality in the Relationship Between Mothers' Parenting Sensitivity and Inhibitory Control and Aggression of Toddlers

\begin{tabular}{|c|c|c|c|c|c|c|c|}
\hline & \multirow[b]{2}{*}{ Pathway } & & \multicolumn{5}{|c|}{ Mediated variables of model } \\
\hline & & & $\beta$ & $S E$ & $t$ & LLCI & ULCI \\
\hline Mothers' parenting sensitivity (A) & $\rightarrow$ & Inhibitory Control & .13 & .04 & $3.03^{* *}$ & .04 & .22 \\
\hline Negative emotionality (B) & $\rightarrow$ & Inhibitory Control & -.16 & .02 & $-7.15^{* * *}$ & -.20 & -.11 \\
\hline \multirow[t]{3}{*}{$\mathrm{A} \times \mathrm{B}$} & $\rightarrow$ & Inhibitory Control & .09 & .03 & $2.48^{*}$ & .02 & .17 \\
\hline & \multirow{2}{*}{\multicolumn{2}{|c|}{ Pathway }} & \multicolumn{5}{|c|}{ Dependent variables of model } \\
\hline & & & $\beta$ & $S E$ & $t$ & LLCI & ULCI \\
\hline Mothers' parenting sensitivity (A) & $\rightarrow$ & Aggression & -.07 & .06 & -1.16 & -.19 & .04 \\
\hline Inhibitory Control & $\rightarrow$ & Aggression & -.73 & .08 & $-9.17^{* * *}$ & -.89 & -.58 \\
\hline Negative emotionality (B) & $\rightarrow$ & Aggression & .02 & .03 & .76 & -.04 & .09 \\
\hline$A \times B$ & $\rightarrow$ & Aggression & .04 & -.05 & -.87 & -.14 & .05 \\
\hline \multicolumn{3}{|c|}{ Index of moderated mediation } & \multicolumn{3}{|c|}{ SEL } & LCI & ULCI \\
\hline \multicolumn{3}{|c|}{-.07} & \multicolumn{3}{|c|}{.03} & -.13 & -.00 \\
\hline
\end{tabular}

Note. $N=277 . \mathrm{LLCI}=$ Lower limit confidence interval; $\mathrm{ULCL}=$ Upper licit confidence interval.

${ }^{*} p<.05 .{ }^{* *} p<.01 .{ }^{* * *} p<.001$.

Table 6

Conditional Indirect Effect of Inhibitory Control

\begin{tabular}{lcccc}
\hline \multicolumn{1}{c}{ Negative emotionality } & Effect & $S E$ & LLCI & ULCI \\
\hline$-1 S D(-.99)$ & -.03 & .04 & -.13 & .06 \\
$M(0)$ & -.10 & .03 & -.17 & -.03 \\
$+1 S D(.99)$ & -.17 & .04 & -.27 & -.08 \\
\hline
\end{tabular}

Note. $N=277$. LLCI $=$ Lower limit confidence interval; ULCL $=$ Upper licit confidence interval.

결과를 통해 어머니의 양육민감성이 걸음마기 아동의 공격성 에 미치는 영향에서 억제통제에 의한 부정적 정서성은 조절된 매개역할을 하고 있음을 확인하였다. 이에 부정적 정서성의 구체적인 유의성을 확인하기 위하여 조건부 간접효과를 확인 한 결과 Table 6과 같다.

Table 6에 의하면, 하한값(LLCI)와 상한값(ULCI) 사이에 0 을 포함하고 있는 부정적 정서성이 낮은 아동을 제외한 나머 지 수준에서는 유의한 조건부간접효과가 있음을 알 수 있다. 구체적으로 살펴보면 부정적 정서성 수준이 높아질수록 값이 증가하는 것으로 확인할 수 있다. 또한 유의한 수준에서 조건 부간접효과의 계수가 음수이므로 조건부간접효과가 부적인 영향을 미침을 알 수 있다. 즉, 부정적 정서성의 수준이 평균이 거나 그보다 높아질수록 조절된 매개효과 값이 더 커진다. 이 는 부정적 정서성의 수준이 평균이거나 그 보다 높을수록 어 머니의 양육민감성이 억제통제를 매개로 공격성을 낮출 수 있 는 반면, 부정적 정서성 수준이 낮은 아동의 경우 이러한 매개 효과가 유의하지 않음을 의미한다.

\section{Discussion}

본 연구는 24-36개월 걸음마기 아동 277 명과 그들의 어머니와 보육교사를 대상으로 어머니의 양육민감성이 억제통제를 매 개로하여 공격성에 미치는 간접효과가 부정적 정서성에 따라 다르게 작용하는 기제를 살펴봄으로써 걸음마기 공격성에 대 한 이해와 예방적 개입을 돕기 위한 목적으로 이루어졌다. 본 연구의 연구결과를 요약하고 논의하면 다음과 같다.

첫째, 걸음마기의 억제통제는 어머니의 양육민감성이 걸 음마기 아동의 공격성에 영향을 미치는 과정에서 완전매개역 할을 하는 것으로 나타났다. 이는 아동의 억제통제가 어머니 의 온정적이고 지지적인 양육행동이 아동의 공격성에 미치는 영향에서 매개역할을 한다는 선행연구결과와 일치한다(Kong \& Lim, 2012; B. Park \& Noh, 2020; Sulik et al., 2015; van Dijk et al., 2017). 이러한 연구결과는 외부조절자로서 어머니의 역 할을 강조하며, 연령이 낮을수록 정서적으로 안정적인 어머 니와의 상호작용의 이점을 보고한 연구 결과(Granic, O'Hara, 
Pepler, \& Lewis, 2007; van Dijk et al., 2017)와도 맥을 같이한다. 따라서 어머니의 양육민감성이 높을수록 자녀와 안정적인 관계를 형성할 수 있으며, 이러한 관계의 이점을 통해 걸음마 기 아동의 억제통제가 증진되며, 결과적으로 공격적인 행동을 적게 보이는 것으로 해석된다. 어머니가 걸음마기 자녀에게 온 정이고 민감한 반응의 양육행동을 많이 보일수록 아동은 지지 적인 관계를 통해 정서적, 심리적 안정감을 느끼며 어머니의 행동을 모방하여 자신의 행동을 계획하고 상황에 적절하게 조 절할 수 있는 억제통제가 발달하며 결과적으로 충동적이고 부 적절한 행동을 억제하여 공격적인 행동을 덜 보이는 것으로 이 해해볼 수 있다. 그러므로 억제통제와 같은 자기조절 능력을 점진적으로 발전하고 내면화하기 위해서는 어머니의 온정적 이고 민감하고 반응적인 양육의 중요성을 강조해야 할 것이다.

둘째, 어머니의 양육민감성이 억제통제에 미치는 관계에 서 걸음마기 아동의 부정적 정서성의 조절효과가 있는 것으 로 확인되었다. 즉, 어머니의 양육민감성이 높을수록 억제통 제가 높게 나타났으나 이러한 효과는 부정적 정서성이 낮은 아동을 제외하고 평균이나 그보다 높은 아동에게서만 유의미 하였다. 이는 차별적 민감성가설(Belsky, 1997)을 지지하는 결 과로 부정적 정서성이 높은 아동의 경우에서만 어머니의 온정 적이고 지지적인 양육환경과 지원의 영향으로 더 높은 억제통 제를 보였다는 선행연구(Cipriano-Essel et al., 2013; S. Kim \& Kochanska, 2012)와 맥을 같이한다. 이러한 결과는 민감하고 까다로운 기질의 아동들이 그렇지 않은 아동들보다 어머니가 제공하는 온정적인 양육환경과 민감하게 반응하는 양육의 유 익성이 크게 나타나 충동적이거나 부적절한 행동을 억제하는 능력인 억제통제를 더 효과적으로 발달시킴을 의미한다. 즉, 어머니는 생애 초기부터 자녀의 행동에 대한 외부 조절자 역 할을 하는데 이때 어머니의 민감하고 반응적인 양육행동은 아 동의 억제통제를 발달할 수 있도록 촉진한다. 특히, 분노와 좌 절 등의 부정적 정서성이 높은 수준의 아동들은 그렇지 않은 아동들보다 긍정적인 양육에 더 민감하게 반응하여 유익한 효 과를 보인다는 연구결과(Pluess \& Belsky, 2010; Roisman et al., 2012)와도 유사한 맥락이다.

따라서 걸음마기 아동의 억제통제를 증진하기 위해서는 부 모와 함께하는 상호작용이 아동의 정신적인 과정의 발달을 촉 진하는 중요한 역할로 강조된다(Valcan et al., 2018). 특히, 일상 적인 상호작용에서 자주 부정적인 정서를 보이는 아동들에게 는 어머니가 보이는 민감하고 반응적인 양육 행동의 유익성이 크게 나타나므로 이러한 양육 기술을 증진할 수 있도록 돕는 부모교육 및 실천 방안이 필요할 것이다.
셋째, 어머니의 양육민감성이 억제통제를 매개하여 걸음마 기 아동의 공격성에 미치는 관계에서 부정적 정서성의 조절된 매개효과는 유의하게 나타났다. 구체적으로 살펴보면 어머니 의 양육민감성이 억제통제를 통해 공격성에 미치는 간접효과 는 부정적 정서성이 낮은 수준을 제외하고 평균과 높은 수준 에서 발생하며 조절효과를 보였다. 어머니의 온정적이고 지지 적인 양육행동이 억제통제를 매개로 하여 공격성에 미치는 관 계를 밝힌 선행연구 결과(Kong \& Lim, 2012; B. Park \& Noh, 2020; Sulik et al., 2015; van Dijk et al., 2017)에서 확장하여 걸 음마기 아동의 공격성에 미치는 억제통제의 영향이 아동의 부 정적 정서성이 수준에 따라 양육의 효과가 다르게 작용함을 밝혔다.

부모는 생애 초기 아동의 외부행동을 조절하거나 관리하 는데 중요한 역할을 하며, 어머니의 온정적이고 지지적인 양 육행동은 억제통제를 촉진한다(Valcan et al., 2018). 이때, 억제 통제는 순한 기질의 아동을 제외하고 부정적 정서성 수준이 높은 아동에게서만 어머니의 양육 유익성을 보고한 CiprianoCipriano-Essel 등(2013)의 연구와 유사한 맥락이며, 이러한 억 제통제가 높은 아동일수록 외현화 문제행동이 낮게 나타난다 는 Buss, Kiel, Morales와 Robinson (2014)의 연구와 맥을 같이한 다.

본 연구는 어머니의 양육행동이 아동 발달에 영향을 줄 수 있는 정도가 아동이 얼마나 환경에 민감한가에 따라 다르게 변화할 수 있다는 Belsky (1997)의 차별적 민감성 가설을 지지 하는 결과로 걸음마기 아동의 공격성에 미치는 억제통제가 아 동의 기질적 특성에 따라 환경에 대한 민감도가 다르게 작용 할 수 있음을 확인하였다. 이는 순한 기질에 비해 까다로운 기 질의 아동은 긍정적인 양육의 유익성이 더 크게 발현되며 아 동의 억제통제를 증진하고 공격성을 감소한 것으로 해석해 볼 수 있다. 따라서 환경에 민감하게 반응하는 까다로운 기질의 아동은 충동적이거나 공격적인 행동을 억제하고 아동이 스스 로 적절한 행동을 함에 있어 부모의 지지적이고 민감한 반응 이 큰 도움으로 작용할 수 있음을 의미한다. 반면, 부정적 정서 성이 낮은 아동에게서는 양육의 유익성이 나타나지 않았다. 이는 부정적 정서성과 공격성의 관계에서 억제통제의 조절효 과를 살펴본 연구(Suurland et al., 2015)에서 어린 연령의 경우 기질적 요인보다 규제전략이 더 중요한 역할을 할 수 있다는 결과를 통해 어머니의 반응적이고 민감한 양육보다는 스캐폴 딩(scaffolding)과 같은 직접적으로 문제 해결 전략을 세워 성공 적인 경험을 쌓는 것이 보다 더 중요하게 작용하였을 것으로 추측해 볼 수 있다. 
결론적으로 본 연구는 어머니의 양육민감성이 높아지면 아 동의 억제통제는 높아지고 공격성은 낮아지는 매개모형이 성 립하였으며, 이 매개효과를 부정적 정서성이 조절하는 조절된 매개모형도 성립됨을 확인하여 의미 있는 결과를 제시하였다. 이러한 결과를 통해 어머니의 양육민감성이 억제통제를 매개 로하여 공격성에 미치는 간접효과가 부정적 정서성에 따라 다 르게 작용함을 밝혔다. 즉, 아동의 부정적 정서성이 높을수록 그렇지 않은 아동들보다 어머니의 민감하고 반응적인 양육환 경에 더 많은 이익을 얻음으로써 어머니와의 안정적인 관계를 통해 충동적인 행동을 조절할 수 있는 억제통제를 효율적으로 발달시켜 공격성을 감소하는 역할로 작용할 수 있음을 시사한 다. 또한, 아동의 억제통제는 자기조절의 핵심 요소로써 초기 의 긍정적인 부모-자녀 상호작용은 각성 조절에서부터 복잡 한 실행능력에 이르기까지 아동의 자기조절 능력과 밀접한 관 련성(Roskam, 2018; Sulik et al., 2015)이 보고된다. 각성을 조절 하는 데 어려움이 있는 아동의 경우 자기의 행동을 조절하는 능력의 발달을 촉진하는 초기 관계가 매우 중요한 반면, 효과 적인 생리적 조절능력을 갖춘 아동에게는 이러한 지지 기반은 덜 중요할 수 있다. 그러므로 아동의 기질적 수준의 차이에 따 라 민감하고 반응적인 양육의 효과가 다르게 나타날 수 있으 므로 이에 대한 이해를 확장해야 할 것이다.

마지막으로 본 연구의 제한점과 후속 연구를 위해 다음과 같이 제언한다. 첫째, 본 연구는 걸음마기 아동의 발달특성을 고려하여 부정적 정서성과 억제통제의 조절된 매개효과를 살 펴보았다. 그러나 아동이 성장함에 따라 정서행동 발달에 미 치는 개인내적인 요소들의 영향이 달라질 수 있으므로 어머니 의 양육민감성이 각 발달연령에 따라 어떠한 상호작용 효과 를 보이는지 살펴본다면 다른 결과를 예측해 볼 수 있을 것이 다. 둘째, 본 연구에서는 걸음마기 아동의 발달특성을 고려하 여 억제통제를 주로 살펴보았으나 실행기능의 경우 연령이 증 가할수록 점진적으로 그 역할이 분화되는 것으로 밝혀지고 있 다(Gandolfi et al., 2014). 따라서 억제통제 능력뿐만 아니라 전 환, 작업기억과 관련하여 초기 형태의 실행기능의 개별적인 능력의 차이가 공격성에 미치는 영향에 대해 종합적으로 살펴 보는 추후 연구가 필요할 것이다. 셋째, 본 연구는 횡단적 연구 설계를 통해 변인들을 살펴보았다. 실행기능의 경우 연령에 따른 변화의 차이를 보고(S. Kim, 2018)하므로 종단 설계를 통 하여 실행 기능과 아동의 공격성 간의 연관성을 시간적 순서 로 조사해서 살펴본다면 다른 결과를 예측해 볼 수 있을 것이 다. 넷째, 본 연구에서는 아동의 부정적 정서성의 기질적 특성 만 고려하여 살펴보았다. 그러나 아동의 낮은 의도적 통제 특
성이나 지나친 활동적 기질 특성도 공격성과 관련되기 때문에 (S. L. Kim, 2016) 이후 연구에서는 다양한 기질적 특성들을 함 께 고려하여 초기 어머니와 자녀 관계에 따른 양육의 상호작 용 효과를 분석하는 것이 필요할 것이다.

이러한 제한점에도 불구하고 본 연구는 어머니의 양육민감 성과 공격성의 영향에서 억제통제의 매개효과와 더불어 부정 적 정서성의 조절된 매개효과를 밝혔다. 이는 차별적 민감성 가설을 지지하는 결과로 걸음마기 아동의 부정적 정서성 수준 이 높을수록 민감하고 반응적인 어머니의 양육행동에 큰 영향 을 받아 억제통제가 발달할 수 있으며 이를 통해 공격성이 감 소함을 확인하였다. 이러한 결과를 통해 걸음마기 공격성에 영향을 미치는 변인들과의 관련성에 대한 이해의 폭을 넓혔다 는 것에 학문적 의의가 있다. 본 연구에서 밝혀진 결과를 토대 로 걸음마기 아동의 공격성을 예방하기 위해 어머니의 양육민 감성 및 양육환경의 중요성을 강조하고 아동의 개인적 특성에 따른 양육 효과의 차별성에 대한 이해를 확장해야 할 것이다. 또한, 높은 공격성을 보이는 아동들에게 실천 가능한 부모교 육 및 조기 중재 프로그램의 기초자료로써 활용할 수 있다는 점에 의의가 있다.

\section{Notes}

This article is a part of the first author's master's thesis submitted in 2021, and was presented as a poster at the 2020 Annual Fall Conference of the Korean Association of Child Studies.

\section{Conflict of Interest}

No potential conflict of interest relevant to this article was reported.

\section{References}

\section{In English}

Ainsworth, M. D. S., Bell, S. M., Stayton, D. J. (1971). Individual differences in strange situation behavior of one-year-olds. In H. R. Schaffer (Ed.), The origins of human relationships (pp. 17-57). London: Academic Press.

Ainsworth, M. D. S., Blehar, M. C., Waters, E., \& Wall, S. N. 
(1978). Patterns of attachment: A psychological study of the strange situation. Hillsdale, NJ: Lawrence Erlbaum Associates.

Bates, J. E., Pettit, G. S., Dodge, K. A., \& Ridge, B. (1998). Interaction of temperamental resistance to control and restrictive parenting in the development of externalizing behavior. Developmental Psychology, 34(5), 982-995. doi:10.1037/00121649.34.5.982

Belsky, J. (1984). The determinants of parenting: A process model. Child Development, 55(1), 83-96. doi:10.2307/1129836

Belsky, J. (1997). Theory testing, effect-size evaluation, and differential susceptibility to rearing influence: The case of mothering and attachment. Child Development, 68(4), 598600. doi:10.1111/j.1467-8624.1997.tb04221.x

Belsky, J., \& Pluess, M. (2009). Beyond diathesis stress: Differential susceptibility to environmental influences. Psychological Bulletin, 135(6), 885-908. doi:10.1037/a0017376

Best, J. R., Miller, P. H., \& Jones, L. L. (2009). Executive functions after age 5: Changes and correlates. Developmental Review, 29(3), 180-200.

Bernier, A., Carlson, S. M., \& Whipple, N. (2010). From external regulation to self-regulation: Early parenting precursors of young children's executive functioning. Child Development, 81(1), 326-339. doi:10.1111/j.1467-8624.2009.01397.x

Blair, C., Raver, C. C., Berry, D. J., \& Family Life Project Investigators. (2014). Two approaches to estimating the effect of parenting on the development of executive function in early childhood. Developmental Psychology, 50(2), 554-565. doi:10.1037/a0033647

Blair, C., \& Ursache, A. (2011). A bidirectional model of executive functions and self-regulation. In K. D. Vohs \& R. F. Baumeister (Eds.), Handbook of self-regulation: Research, theory, and applications (2nd ed., pp. 300-320). New York: Guilford Press.

Bornstein, M. H., Tamis-LeMonda, C. S., Pascual, L., Haynes, O. M., Painter, K. M., Galperin, C. Z., \& Pecheux, M.-G. (1996). Ideas about parenting in Argentina, France, and the United States. International Journal of Behavioral Development, 19(2), 347-367. doi:10.1177/016502549601900207

Bowlby, J. (2005). A secure base. London: Routledge.

Brownell, C., \& Kopp, C. (2007). Socioemotional development in the toddler years: Transitions \& transformations (Illustrated ed.). New York: Guilford Press.

Buss, K. A., Kiel, E. J., Morales, S., \& Robinson, E. (2014). Toddler inhibitory control, bold response to novelty, and positive affect predict externalizing symptoms in kindergarten. Social Development, 23(2), 232-249. doi:10.1111/sode.12058

Campbell, S. B., Spieker, S., Burchinal, M., Poe, M. D., \& The NICHD Early Child Care Research Network. (2006). Trajectories of aggression from toddlerhood to age 9 predict academic and social functioning through age 12 . Journal of Child Psychology and Psychiatry, 47(8), 791-800. doi:10.1111/j.1469-7610.2006.01636.x

Cipriano-Essel, E., Skowron, E. A., Stifter, C. A., \& Teti, D. M. (2013). Heterogeneity in maltreated and non-maltreated preschool children's inhibitory control: The interplay between parenting quality and child temperament. Infant and Child Development, 22(5), 501-522. doi:10.1002/icd.1801

Denissen, J. J. A., Thomaes, S., \& Bushman, B. J. (2017). Selfregulation and aggression: Aggression-provoking cues, individual differences, and self-control strategies. In D. De Ridder, M. Adriaanse, \& K. Fujita (Eds.), The Routledge international handbook of self-control in health and well-being (pp. 330-339). Abingdon-on-Thames, UK: Routledge.

Diamond, A. (2013). Executive functions. Annual Review of Psychology, 64, 135-168. doi:10.1146/annurev-psych-113011-143750

Diamond, A. (2016). Why improving and assessing executive functions early in life is critical. In J. A. Griffin, P. Mc Cardle, \& L. S. Freund (Eds.), Executive function in preschoolage children: Integrating measurement, neurodevelopment, and translational research (pp. 11-43). Washington, DC: American Psychological Association.

Gandolfi, E., Viterbori, P., Traverso, L., \& Usai, M. C. (2014). Inhibitory processes in toddlers: A latent-variable approach. Frontiers in Psychology, 5, 1-11. doi:10.3389/fpsyg.2014. 00381

Garon, N., Bryson, S. E., \& Smith, I. M. (2008). Executive function in preschoolers: A review using an integrative framework. Psychological Bulletin, 134(1), 31-60. doi:10.1037/00332909.134.1.31

Granic, I., O’Hara, A., Pepler, D., \& Lewis, M. D. (2007). A dynamic systems analysis of parent-child changes associated with successful "Real-world" interventions for aggressive children. Journal of Abnormal Child Psychology, 35, 845857. doi:10.1007/s10802-007-9133-4

Grossmann, K. E., \& Grossmann, K. (1991). Attachment quality as an organizer of emotional and behavioral responses in a longitudinal perspective. In C. M. Parkes, J. StevensonHinde, \& P. Marris (Eds.), Attachment across the life cycle (pp. 93-114). London: Tavistock/Routledge.

Hay, D. F., Perra, O., Hudson, K., Waters, C. S., Mundy, L., Phillips, R.,...van Goozen, S. (2010). Identifying early signs of aggression: Psychometric properties of the Cardiff Infant Contentiousness Scale. Aggressive Behavior, 36(6), 351-357. doi:10.1002/ab.20363

Hay, D. F., Waters, C. S., Perra, O., Swift, N., Kairis, V., Phillips, R.,...van Goozen, S. (2014). Precursors to aggression are evident by 6 months of age. Developmental Science, 17(3), 471-480. doi:10.1111/desc. 12133

Hayes, A. F. (2018). Partial, conditional, and moderated moderated 
mediation: Quantification, inference, and interpretation. Communication Monographs, 85(1), 4-40. doi:10.1080/036 37751.2017.1352100

Hong, S., Malik, M. L., \& Lee, M.-K. (2003). Testing configural, metric, scalar, and latent mean invariance across genders in sociotropy and autonomy using a non-Western sample. Educational and Psychological Measurement, 63(4), 636-654. doi:10.1177/ 0013164403251332

Isquith, P. K., Gioia, G. A., \& Espy, K. A. (2004). Executive function in preschool children: Examination through everyday behavior. Developmental Neuropsychology, 26(1), 403-422. doi:10.1207/s15326942dn2601_3

Kim, S., \& Kochanska, G. (2012). Child temperament moderates effects of parent-child mutuality on self-regulation: A relationship-based path for emotionally negative infants. Child Development, 83(4), 1275-1289. doi:10.1111/j.14678624.2012.01778.x

Kochanska, G., Kim, S., Barry, R. A., \& Philibert, R. A. (2011). Children's genotypes interact with maternal responsive care in predicting children's competence: Diathesis-stress or differential susceptibility? Development and Psychopathology, 23(2), 605-616. doi:10.1017/S0954579411000071

Lahey, B. B., van Hulle, C. A., Keenan, K., Rathouz, P. J., D’Onofrio, B. M., Rodgers, J. L.,...Waldman, I. D. (2008). Temperament and parenting during the first year of life predict future child conduct problems. Journal of Abnormal Child Psychology, 36, 1139-1158. doi:10.1007/s10802-0089247-3

Maccoby, E. E. (2007). Historical overview of socialization research and theory. In J. Grusec \& P. Hastings (Eds.), Handbook of socialization: Theory and research (pp. 13-41). New York: Guilford Press.

Morasch, K. C., \& Bell, M. A. (2011). The role of inhibitory control in behavioral and physiological expressions of toddler executive function. Journal of Experimental Child Psychology, 108(3), 593-606. doi:10.1016/j.jecp.2010.07.003

NICHD Early Child Care Research Network., \& Arsenio, W. F. (2004). Trajectories of physical aggression from toddlerhood to middle childhood: Predictors, correlates, and outcomes. Monographs of the Society for Research in Child Development, 69(4), i-143.

Pluess, M., \& Belsky, J. (2010). Differential susceptibility to parenting and quality child care. Developmental Psychology, 46(2), 379-390. doi:10.1037/a0015203

Roisman, G. I., Newman, D. A., Fraley, R. C., Haltigan, J. D., Groh, A. M., \& Haydon, K. C. (2012). Distinguishing differential susceptibility from diathesis-stress: Recommendations for evaluating interaction effects. Development and Psychopathology, 24(2), 389-409. doi:10.1017/S0954579412000065

Roskam, I. (2018). Externalizing behavior from early childhood to adolescence: Prediction from inhibition, language, parenting, and attachment. Development and Psychopathology, 31(2), $587-$ 599. doi:10.1017/S0954579418000135

Rothbart, M. K., \& Bates, J. E. (2006). Temperament. In W. Damon, R. M. Lerner, \& N. Eisenberg (Eds.), Handbook of child psychology: Social, emotional, and personality development (Vol. 3, pp. 99-166). Hoboken, NJ: John Wiley \& Sons.

Spangler, G., Schieche, M., Ilg, U., Maier, U., \& Ackermann, C. (1994). Maternal sensitivity as an external organizer for biobehavioral regulation in infancy. Developmental Psychobiology, 27(7), 425-437. doi:10.1002/dev.420270702

Stams, G.-J. J. M., Juffer, F., \& van IJzendoorn, M. H. (2002). Maternal sensitivity, infant attachment, and temperament in early childhood predict adjustment in middle childhood: The case of adopted children and their biologically unrelated parents. Developmental Psychology, 38(5), 806-821. doi:10.1037/0012-1649.38.5.806

Sulik, M. J., Blair, C., Mills-Koonce, R., Berry, D., Greenberg, M., \& Family Life Project Investigators. (2015). Early parenting and the development of externalizing behavior problems: Longitudinal mediation through children's executive function. Child Development, 86(5), 1588-1603. doi:10.1111/cdev.12386

Suurland, J., van der Heijden, K. B., Huijbregts, S. C. J., Smaling, H. J. A., De Sonneville, L. M. J., van Goozen, S. H. M., \& Swaab, H. (2015). Parental perceptions of aggressive behavior in preschoolers: Inhibitory control moderates the association with negative emotionality. Child Development, 87(1), 256269. doi: $10.1111 /$ cdev. 12455

Tremblay, R. E. (2000). The development of aggressive behaviour during childhood: What have we learned in the past century? International Journal of Behavioral Development, 24(2), 129141. doi:10.1080/016502500383232

Tremblay, R. E. (2010). Developmental origins of disruptive behaviour problems: The 'original sin' hypothesis, epigenetics and their consequences for prevention. Journal of Child Psychology and Psychiatry, 51(4), 341-367. doi:10.1111/ j.1469-7610.2010.02211.x

Valcan, D. S., Davis, H., \& Pino-Pasternak, D. (2018). Parental behaviours predicting early childhood executive functions: A meta-analysis. Educational Psychology Review, 30, $607-$ 649. doi:10.1007/s10648-017-9411-9

van Aken, C., Junger, M., Verhoeven, M. A. G., van Aken, M. A., Deković, M., \& Denissen, J. J. A. (2007). Parental personality, parenting and toddlers' externalising behaviours. European Journal of Personality, 21(8), 993-1015. doi:10.1002/per.643

van Dijk, R., Deković, M., Bunte, T. L., Schoemaker, K., Zondervan-Zwijnenburg, M., Espy, K. A., \& Matthys, W. (2017). Mother-child interactions and externalizing behavior problems in preschoolers over time: Inhibitory control as a mediator. Journal of Abnormal Child Psychology, 45(8), 1503- 


\section{7. doi:10.1007/s10802-016-0258-1}

van Zeijl, J., Mesman, J., Stolk, M. N., Alink, L. R. A., van IJzendoorn, M. H., Bakermans-Kranenburg, M. J.,...Koot, H. M. (2007). Differential susceptibility to discipline: The moderating effect of child temperament on the association between maternal discipline and early childhood externalizing problems. Journal of Family Psychology, 21(4), 626-634. doi:10.1037/0893-3200.21.4.626

Verhoeven, M., Junger, M., van Aken, C., Deković, M., \& van Aken, M. A. (2010). Parenting and children's externalizing behavior: Bidirectionality during toddlerhood. Journal of Applied Developmental Psychology, 31(1), 93-105. doi:10.1016/j.appdev.2009.09.002

\section{In Korean}

Chung, J. (2017). Predicting children's behavior problems from temperamental attributes and maternal responsiveness during preschool period. Korean Journal of Child Studies, 38(2), 119132. doi:10.5723/kjcs.2017.38.2.119

Hong, N., \& Bang, H. (2018). Effect of an attachment-based parental education program on enhancing parenting sensitivity and attachment security. Journal of Cognitive Enhancement and Intervention, 9(2), 91-108. doi:10.21197/JCEI.9.2.5

Kim, B. Y. (2005). Analysis on mother's rearing attitude, sex, period of day-care influencing infants's problem behaviors (Master's thesis). Retrieved from http://www.riss.kr/link?id=T9831426

Kim, J. (2016). Mother's parenting beliefs and parenting behavior Effects on social withdrawal and aggression in toddler group for children (Master's thesis). Retrieved from http://www. riss.kr/link?id=T14056731

Kim, S. (2018). Trajectories of externalizing behavior problems in young children and its associations with elementary school adjustment and executive function difficulties: Using growth mixture modeling. Korean Journal of Child Studies, 39(6), 4156. doi:10.5723/kjcs.2018.39.6.41

Kim, S. L. (2016). The moderating effects of mothers' parenting styles on the relationship between preschoolers' temperament and their behavior problems. Journal of Life-span Studies, 6(1), 1-20.

Kim, Y. E. (2014). The effect of toddlers' negative emotionality and mothers' reactions to their child's negative emotions of social-emotional behaviors. Journal of Korean Child Care and Education, 10(3) 85-102. doi:10.14698/jkcce.2014.10.3.085

Kong, Y.-S., \& Lim, J.-Y. (2012). The relationships between preschooler's temperament, maternal parenting attitude, preschooler's problem and prosocial behaviors. The Journal of Child Education, 21(4), 135-152.

Lee, H.-K. (2016). Misunderstanding and truth of moderation, moderated mediation and mediated moderation. Korean Journal of Tourism Research, 31(3), 213-248.

Lee, H. M. (2006). The effect of maternal parenting style and sensitivity on infant development (Master's thesis). Retrieved from http://www.riss.kr/link?id=T10532456

Park, B., Kim, M.. Shin, N., Yun, K., \& Noh, J. U. (2019). The effects of maternal parenting behaviors on toddlers' externalizing problem behaviors: The mediating effect of compliance. Korean Journal of Child Studies, 40(2), 57-73. doi: $10.5723 / \mathrm{kjcs} .2019 .40 .2 .57$

Park, B., \& Noh, J. U. (2020). Longitudinal effects of parenting behaviors on early school-age children's problem behaviors: Mediating effect of executive function difficulties. Korean Journal of Child Studies, 41(2), 163-179. doi:10.5723/ kjcs.2020.41.2.163

Park, B.-K. (2013). Relations among toddlers' temperament, maternal parenting, and social withdrawal and aggression. Journal of Korean Home Management Association, 31(6), 6781. doi:10.7466/JKHMA.2013.31.6.67

Seo, J., \& Park, H. (2011). The effects of emotional intelligence on executive function: A comparison between normal children and attention deficit children. Journal of Cognitive Enhancement and Intervention, 2(1), 99-126.

Shim, M. K., \& Woo, J. Y. (2019), The mediating effects of parenting stress, child's temperament and emotional regulation in the relationship between mother's parenting sensitivity and child's school readiness. Korean Journal of Child Studies, 40(5), 6982. doi:10.5723/kjcs.2019.40.5.69

Yoon, J. H., \& Lee, J. H. (1999). A study on toddlers' behavior problems and caregivers' difficulties. Korean Journal of Child Studies, 20(2), 171-186.

Yun, K. B. (2012). Korean mothers' beliefs as related to temperament of their toddler boys and girls (Master's thesis). Retrieved from http://dcollection.ewha.ac.kr/jsp/common/ DcLoOrgPer.jsp?sItemId=000000069528

\section{ORCID}

Seon kyung Kim

Sunhee Kim https://orcid.org/0000-0002-1313-8004

http://orcid.org/0000-0002-0801-6918
Received December 31, 2020

Revision received January 22, 2021

Accepted January 25, 2021 